\title{
The leadership role of emeritus Archbishop Desmond Tutu in the social development of the South African society
}

\author{
Pali, KJ ${ }^{1}$ \\ University of the Free State, Bloemfontein, South Africa \\ palikj@ufs.ac.za
}

\begin{abstract}
Leadership of the ministers of the Word is often restricted to within church boundaries, on the pretext that ministers should be religious and not too involved in the "world". On the other hand, ministers are involved in social issues mostly to address immediate needs, often at the expense of transforming the unjust system that perpetuates social injustices. Emeritus Archbishop Desmond Tutu practised his leadership ministry within and beyond the church boundaries. In the South African society, his leadership ministry contributed towards social development and transformation. This article aims to analyse the contribution of the leadership role of emeritus Archbishop Desmond Tutu in the social development of the South African society. The main research question is to what extent is or was the leadership of emeritus Archbishop Desmond Tutu involved in the social development of the South African society?
\end{abstract}

\section{Keywords}

Social development; transformation; leadership; spirituality; theology

\section{Introduction}

The objective of leadership is change (Tannenbaum, Weschler, Massarik 2013:5). It does not matter whether that change is positive or negative, to an individual or local context. Often, the type of change that takes place in the context of leadership is an accelerated, complex and discontinuous

1 Dr Khamadi Joseph Pali is a lecturer at UFS, Faculty of Theology and Religion, in the Department of Practical and Missional Theology. This article is sponsored by NRF sabbatical grants 2018-2019. I would like to thank Prof Nadine Bowers-Du Toit (Stellenbosch University) for her critical remarks and advice in this article. 
one (Ford 1991:14; Roxburgh \& Romanuk 2006:7). This makes it difficult for leadership to cope and function effectively in every context. For this reason, there is a growing uncertainty as to the role and responsibilities of leadership, especially in contexts such as churches, due to the many challenges facing the leadership (Jinkins 2000:308; Van der Borght 2005:237).

Amid this confusion over the role of leadership, the opinion of some scholars, in their effort to contribute to the role of leadership, should be mentioned. Burns (1979:3) emphasises that leadership should promote human development and actual social change. Tannenbaum et al (2013:5) accentuate that the objective of leadership is change that should impact on the attitude and behaviour of an individual and a group. In a Christian context, Smit (2001:25), Plueddemann (2009:161) and Saines (2010:517) maintain that leadership should enable humanity to experience transforming communion with the Triune God through service to the other and challenging social institutions that perpetuate injustices. This calls for human beings to live as the image of God in the world by being stewards of creation and agents of change of social structures that perpetuate injustices and oppression (Bragg 1987:39).

This article chiefly aims to analyse the contribution of the leadership ministry of Tutu in the social development of the South African society during the apartheid and post-apartheid eras. The first objective of this article is to identify some lessons that can be derived from the leadership of Tutu in the social development of the South African society. The second objective is to assess the impact of the leadership of Tutu on the social development of the South African society. The main research question is to what extent is or was the leadership of Archbishop Emeritus Desmond Tutu involved in the social development of the South African society?

\section{Positioning in Practical Theology}

This study is a practical theological study. Practical Theology studies the actions of believers and their faithful communication of the gospel in a specific context (Schoeman, Laubscher, Pali \& Van Den Berg 2012:129, 131). In addition, this article mainly focuses on the actions and faithful communication of the gospel by the clergy (in this case Archbishop 
Emeritus Desmond Tutu) in church and society. Within the context of Practical Theology, the focus of this article is on leadership and diaconics. Leadership is a process of a quality relationship of influence between a leader and a follower towards the common goal of an organisation. According to Heitink (1999:293, 299), diaconics is the study of activities related to the service of the church or believers towards society. Biblically this diaconial service of the church becomes prophetic when it takes a stand against injustices caused by oppression and corruption and unjust structures that transgress human rights of others (Dietrich 2016:155-160). Furthermore, Heitink (1999:305) argues that diaconal ministry can engage on various levels such as the local congregation, the society in which we live, and the world as a global village. It would be interesting to view how the leadership ministry of Tutu fits within these divisions and levels of diaconate ministry.

\section{A brief life history of Archbishop Emeritus Desmond Tutu}

Tutu was born on 7 October 1931 in Klerksdorp, South Africa. His father was a Xhosa tribesman, his mother a Tswana, and his grandmother a Sothospeaker. The multi-ethnic household, in which Tutu grew up, empowered him to be multilingual, as he could speak at least eight South African languages. This made it easy for him to interact and converse with many people from various backgrounds. His family's denomination shifted from the Methodist church, to the African Methodist Episcopal church, and to the Anglican Church (SAHO 2018). This experience empowered him later to easily partake in interdenominational ministry both in his local and international ministry.

In his younger days, Tutu was impressed by a British priest Trevor Huddleston who, on meeting Tutu's mother, greeted and removed his hat out of respect for her. He provided spiritual consolation to Tutu when he suffered from TB as a teenager (Webster 1982:17; Clarke 2008:340). When Tutu decided to join the ministry, Trevor Huddleston and other Anglican priests inspired and assisted him to study theology and join the ministry in the Anglican church (SAHO 2018). The humanity and passion of Trevor Huddleston against apartheid and other injustices and indignities were some of the attributes which Tutu sought to emulate throughout his life 
(The Cape Times 2013). However, besides Trevor Huddleston, other mentors of Tutu included, among others, Gandhi, Martin Luther King Jr, and the Dalai Lama (Webster 1982:20).

Tutu was a teacher when he married Nomalizo Leah Shenxane who was also a teacher and a member of the Roman Catholic Church; they have four children. But when the apartheid government introduced the Bantu education system in 1953, Tutu left teaching to study for the ministry (Pieterse \& Scheepers 1995:10). In 1958, Tutu enrolled at St Peter's Theological College, Rosettenville, to study Theology. He was ordained a deacon in 1960 and a priest in 1961 (Webster 1982:17, 18; SAHO 2018). As ordained priest, he did his pastoral ministry both locally and internationally.

In his international studies in London, Tutu furthered his studies towards a master's degree (Clarke 2008:340; SAHO 2018). While Tutu was in London, the pastoral ministry made him realise that racism is not only a South African problem; it is also present in London (SAHO 2018). His pastoral ministry to the White community and other denominations in London groomed him well to minister to multiracial congregations in South Africa and interact with other denominations (SAHO 2018). In addition, this pastoral ministry helped him in some way to jettison any bitterness towards White people, and the feeling of racial inferiority, and overcome his automatic deferring to White people (Gish 2004:34).

Tutu demonstrated initiative, and creativity, in the leadership appointments in both the academic institutions, church and other organisations he served. For example, after completing his theological studies abroad, Tutu once worked as a pioneer black academic theologian in various academic institutions both locally and internationally (Clarke 2008:341; Webster 1982:18; Pieterse \& Scheepers 1995:10). As a lecturer in Theology, he wrote articles for journals and magazines and entrenched himself in studies of Black theology, liberation theology, and African theology as part of his intellectual contribution to academic debate in the context of Africa, especially South Africa.

Later, Tutu was appointed in his church as the first Black Dean of Johannesburg (1975-1976) in a racially mixed congregation. In an attempt to transform the ministry of his church, he advocated for ordination of 
women as priests, he was vocal against the nationalist government, and endorsed the economic boycott of South Africa. However, this ministry as Dean of Johannesburg brought mixed results: the number of congregants increased, even though a few White parishioners could not accept a Black man as their spiritual leader (Clarke 2008:417).

Tutu was also appointed as the first Black Bishop of Johannesburg (19851986) in St Mary's Cathedral, which half of its parishes were exclusively White (Crompton 2007:36-60). According to Clarke (2008:417), Tutu was also appointed as the first Black Archbishop of the Church of the Province of South Africa (CPSA) in Cape Town (1986-1996). Some White congregations of the CPSA threatened to withdraw from that church, because they were not happy with Tutu as their leader. Some ministers from his own church even rejected most of Tutu's courageous public statements. In addition, some of the initiatives, for which some of his congregation members reviled him, was when he allowed politicians such as Albertina Sisulu and Allan Boesak to give political speeches after the Eucharist service; he advocated for women ordination and the rights of other minorities such as gays and lesbians.

In relation to faith-based organisations, Tutu was appointed as the first Black General Secretary of the South African Council of Churches (SACC) (1978-1985). Webster (1982:18) states that he used SACC to make a clear call for justice and social reform. SACC was established in the 1940s as an ecumenical organisation for all churches in South Africa, united in one general body. At the SACC, he used his religious piety, daily prayer, regular Bible study, monthly Eucharist, and silent retreat to influence and empower his staff. As part of his leadership empowerment, he delegated most of his work to his senior staff, while he travelled abroad to fundraise for SACC projects (SAHO 2018).

Furthermore, Tutu was a director of the Theological Education Fund for Africa (1972-1975) under the World Council of Churches (WCC), and President of the All Africa Conference of Churches (AACC) (1987-1997). Both these experiences exposed Tutu to the many challenges of African leadership and its churches. As chairperson of the Elders (2007-2009), Tutu was part of a group of world leaders who contributed wisdom, kindness, leadership and integrity in order to engage the world's toughest 
problems (SAHO 2018). Tutu was also appointed as leader of the Truth and Reconciliation Commission (TRC) in 1996-1998 and was let down when the clear majority of the White community failed to take advantage of the TRC process.

In general, Tutu was also a social activist who speaks freely on social issues such as climate change, legalised assisted dying, gay and lesbian rights, as well as children's and women's rights. He also worked as advisor and mediator for the United Nations. During the apartheid era, Tutu's international visits helped him develop more hope for the future of his own country. In the post-apartheid era, Tutu used his international visits to campaign for economic investment in South Africa and to spread a word of gratitude to those countries that contributed to the downfall of apartheid.

Since Tutu is a prominent and world-renowned leader, he received over thirty doctoral degrees from local and international institutions as well as many other international accolades such as the Nobel Peace Prize award (1984), and the Martin Luther King Jr Non-Violent Peace Prize award (Clarke 2008). It appears that the extent of Tutu's leadership ministry denied him the opportunity to retire. He announced his retirement in 1996 and 2010. But, he is still seen in public responding to some public concerns. In summary, the expertise, knowledge, and life skills that Tutu gained from his childhood days, his travelling and work experience within and beyond the church truly prepared Tutu for the ministry within the South African society and beyond

\section{Tutu's view on leadership and its role}

How did Tutu understand leadership? Tutu's $(2010: 46,60)$ theology and identity in Christ guided his leadership ministry in the development of the South African society. Tutu viewed himself as a minister not only of Black people, but also of all children of God. As a result, he believed that, for the kingdom of God and the church to grow, he must as a minister proclaim the gospel and provide a service to those in need, even beyond the boundaries of the church and this compelled him to regularly address issues traditionally not associated with the concerns of the church. In short, Tutu believes that church leadership should not be confined to the church environment; hence his leadership ministry spoke out in many diverse 
situations, and he used the press as vehicle of communication (Webster 1982:16).

Tutu (1994:229) believes that, in leadership, authority, power and glory must be linked with service and be shared. For example, he delegated some of his leadership responsibilities for the sake of empowering the other and to achieve that as Archbishop of Cape Town, he often used a consensusbuilding approach to leadership in order to avoid competition and to work towards a unanimous decision.

However, sometimes some situations prompted for other approaches that were not consistent with consensus building approach to leadership. For example, according to Allen (2006: 308, 337) Tutu, after the disastrous demonstrations immediately preceding the 1989 elections, Tutu (after much prayer) decided, against the advice of others in the Defiance Campaign, to announce another march. When challenged (by Cheryl Carolus), Tutu replied, "God told me, and I'm afraid we can't argue with God." (Allen 2006:308). In 1994, when several priests in the CPSA announced publicly they were supporting ANC because of its manifesto, that they believed contain "the gospel values of an inclusive society", Tutu called them to Bishops Court and demanded they apologize or lose their licenses (Allen 2006:337).

Tutu (2010:29) understands leadership as being present and available for the sake of those we lead. In his opinion, leadership demonstrates selfsacrificial leadership when it serves others and is prepared to suffer and die for Christ. This means that, when people experience pain, loss and suffering, a leader should volunteer, initiate a process to help, and sacrifice his time and resources in order to help those in need. For example, after receiving his money for the Nobel Peace Prize award, he shared it with his family and SACC staff and even established a scholarship fund for South Africans in exile (Gish 2004:95).

Tutu is an icon of South African society; he leaves a lasting legacy of effective and transforming Christian leadership in the social development of the South African society. Since leadership is about relationships of influence, it is necessary to note various techniques such as integrity, values, self-concept, authenticity and spirituality that can be used to transform the attitudes and lifestyles of the followers (The Wheaton '83 
Statement 1987:262; Chakraborty \& Chakraborty 2004:204). Tutu used some of these techniques to influence many of his followers. For example, Tutu emphasised good Christian values such as love, reconciliation, peace, and caring for each other. As part of his self-concept, Tutu understood himself as a servant of God, agent of change, father to others, and moral sage to society and it is notable that Tutu's spirituality empowered him to demonstrate the authenticity of his words, actions and influence. As part of his spiritual practices, Tutu prayed, participated in the Eucharist and silent retreats, meditated, and studied the scripture to help him empower others and serve God and his society more (Clarke 2008:416). Tutu's insistence on a sound spirituality, respect of dignity of human life, justice and reconciliation made him a minister and a leader with integrity; he was respected both locally and internationally.

How did Tutu view leadership in Africa? Tutu (1982: 113), was concerned about the situation of the formerly colonised countries and their people. This includes most of African countries and South Africa as well. He believes the situation of these formerly colonised countries is worse under their own rulers than under the colonial masters. He argues that, some of these previously colonised countries, frown upon those who try to criticise the abuse of power by totalitarian military dictators. Hence, political dissent is not favoured, there is no smooth transition of leadership, and corruption is rife. With specific reference to Africa, Tutu stated the following: "It pains me to have to admit that there is less freedom and personality in most independent Africa than there was during the much-maligned colonial days." (Tutu 2010:1). Tutu does believe that there are some good leaders in Africa, but he blames the degrading situation of Africa on those rulers who were ruthless, vicious, corrupt, accountable to no one, engaged in selfenrichment schemes, and living a luxurious life (Tutu 2007:v).

\section{Tutu's theology towards a Christian involvement in society}

A sound theology of leadership should have a good biblical understanding of how God views humanity, church and the world. Biblical knowledge about leadership does not suffice; it should be accompanied by a passion to emulate and act the will of God on earth. What is theology of Tutu towards his involvement in society? 


\subsection{Influence of Anglo Catholicism}

Tutu in his ministerial training and practices he was exposed to the teachings and practices of Anglo Catholicism (Lynch 2017). Allen (2006:64, 66) says that Tutu was trained as priest at St Peter's Theological College which was founded by the Community of the Resurrection who were strong adherents of Anglo Catholicism within the Anglican church. The spiritual practices and teachings of Anglo Catholicism of these members of the Community of Resurrection made an indelible mark on the spirituality and daily ministry of Tutu (Tutu 2010:17).

Anglo Catholicism is a movement or one of the influential traditions within the Anglican Church. According to Lynch (2017), Anglo Catholicism started in the $19^{\text {th }}$ century within the Anglican church in England and spread within the Anglican communion globally (Lynch 2017). It is associated with high church theology of the tractarians, and regards as significant the episcopal form of church government, the sacraments, and liturgical worship with some of the rituals of the liturgy adopted from the Roman Catholic Church practices. Concerning the church; the adherents of Anglo Catholicism believe that it is founded by God, built on the foundation of the apostles and prophets, and its existence is guaranteed by the apostolic succession of its bishops.

In relation to social involvement the adherents of this Anglo Catholic movement believed that: A true and personal devotion to God must empower one to reach out to the other (Clark 1961:23,24,79). Hence, the rituals of the liturgy must empower and prepare the participants for the mission of God in the world (Kemper 2016:6). Barnett $(2016: 2,3)$ adds that the adherents to this movement teach incarnational theology that emphasizes that God loved the world so much that He chose no only to be with us, but to be one of us. They also adhere to critical reading of the scripture and influenced by social action movement theories. In their actual social involvement adherents to Anglo Catholicism strive for physical involvement and presence in order to bring about a concrete solution to the challenges of the poor, marginalized and the oppressed (Kemper 2016:4). To them their Christian faith must influence every aspect of life and human society and confront injustices of the societal institutions. Hence their concern is for the well-being of all humanity and other creations of God (Barnett 2016:3). 
In summary, Anglo-Catholic movement is a force for social change and social justice (Kemp 2016:4). In South Africa the Anglo Catholic movement inspired people like Desmond Tutu and Trevor Huddleston to become social activists to confront injustices of Apartheid system and fought for the racial equality of all South African citizens (Barnett 2016:9, 10).

\subsection{Tutu's theology on humanity}

Tutu (1994:113; 2010:44) believes that, humanity is endowed with the image of God; therefore, humanity is a respectful and special creation of God. Therefore, no one is an accident or a non-entity to God; everyone is somebody. With reference to the nature of the human being, Tutu (2005:13, $14,18)$ perceives that the human being is a mixture of bad and good, with a moral responsibility and freedom to choose either to be kind or cruel. Even though Tutu $(2005: 2,5)$ is concerned about the evil and cruel acts that dominate the world and our lives, he is not pessimistic and hopeless about the situation when he states that evil, injustice, oppression and lies should not have the last word, as they are against the yearning that God placed in our hearts. Our hearts yearn for goodness and the will of God (Romans 7: 19), because as creation of God we are initially created good (Genesis 1, 2) and endowed with the image of God. According to Tutu and Tutu (2010:5), we are fundamentally good and thus have the potential to do good and partner with God in serving His creation. Tutu $(2005: 22,25)$ states that humanity is all God's family characterised by interdependence, sharing of resources, and no discrimination. To further demonstrate the goodness of humanity in the context of South Africa, Tutu (2005:7) uses the metaphor of a rainbow people to emphasise that our diversity should not deter us from working together for peace and prosperity.

\subsection{Role of religion in society}

Tutu (1994:29, 30, 31) believes Christian religion is founded on true faith in God who rules all of life in both its secular and sacred aspects; humanity should experience the transforming power of God against social ills. Tutu's understanding of religion is modelled on what Christ has done; it is more functional and transforming rather than simply decorative and conforming. For example, Tutu (1994:71; 2005:64) perceives religion to be not only about personal piety or limited to private space, but also as integrated with life 
issues. To Tutu (1994:71; 2005:64), this means that religion must give hope to people, advocate for the course of the oppressed, and mobilise humanity to challenge the unjust social policies, systems and institutions. It is for this reason that, in his congregational and social ministry, Tutu refuses to be subdued by the pressure to desist speaking against unjust political systems. After his arrest and detainment at John Vorster prison for partaking in the march protesting the detention of Rev. J. Thorne, Tutu stated (Webster 1982:18): "No longer are we going to be churches that merely pass pious resolutions. Since then, he has refused to carry a pass other than a passport or driver's license."

Furthermore, Tutu believes that Christian religion compels us to witness to the people of other faiths. He is involved in interreligious ministry among Christians, Hindus and Muslims (Clarke 2008:424). To Tutu (1982:28, 32, 114; 2010:17, 64, Christian religion is our motive for sociopolitical involvement, and religion cannot be neutral, that is, religion must support the oppressed, the suffering and the marginalise. In addition, Tutu (1982:29) mentions that our faith as members of different churches should motivate us towards concrete action that transforms the situation of those who are hungry, naked, sick and imprisoned; this qualifies us for heaven. This convinced Tutu that a church that ignores its role in social involvement is irrelevant and blasphemous in the ministry of God.

In summary, to Tutu, our Christian faith must motivate us to be socially involved. Hence, the use of religion as a form of escapism or skulking behind prayers is not an authentic Christian spirituality (Tutu 1982:30, Clarke 2008:341). By contrast, a mere worldly "busyness" or "activism" is not an authentic Christian spirituality if not motivated by true faith in Christ and the confrontation of the injustices of evil social structures (Tutu 1982:30).

\subsection{Church}

Church is often defined as people called by God, a community of believers, or a divine institution. Tutu (1994:114; 1982:31-36, 39, 114, 116; 2010:16) uses various metaphors to describe the concept of a church: the salt and light of the world; a community of the reconciled; a forgiven community; an 
alternative community; a caring and compassionate society; a fellowship of adoration; a family; a sign in the world, and the first fruits of the kingdom.

Tutu $(1982: 31,32)$ believes that church has a diverse and transforming role to play in society. He mobilised his church members to take part in confronting the unjust social ills. For example, Tutu mentions that a church must give hope to the hopeless and transfigure a situation of hate, brokenness and separation, fear and bitterness. It is an alternative society that must be compassionate and caring, instead of harsh and insensitive. Where people are statistics, we must show that they are of value to God. We must share the community, instead of being selfish. The church must witness by service to others such as the sick, the hungry, the lepers, the disabled, and the naked. The church of God is fearless in proclaiming the gospel and is prepared to suffer, to be vilified, and to be ostracised. A church must be prophetic, give hope, and oppose injustice, violence, oppression, exploitation, and inhumanity. Tutu also mentions that the church's involvement in socio-economic matters must be motivated by the imperatives of the gospel and not by political motives. The church must be prepared to pay the prize for its loyalty to Christ. Churches are agents of reconciliation, unity, and justice. Division among churches makes it difficult for people to believe in a gospel; it makes the church an ineffective witness and wasteful. The church must be on the side of the poor and the oppressed (Clarke 2008:368).

The church has a responsibility to the rich and the poor, the ruler and the ruled, the oppressed and the oppressor, but it needs to point out that God does take sides. The church is the salvation of Africa, even though the church in Africa is facing the challenges of injustice, corruption, oppression, exploitation, as well as the gap between the rich and the poor (Tutu 2010:1). In summary, to Tutu (1994:114; 2010:16), the church's role is concrete action, not merely talk (Tutu 1982:31). The church's agenda is liberation of humanity to be all that God wants us to be and to demonstrate what God intends a human society to be.

\subsection{Church in relation to politics and the state}

How ministers and churches should relate with politics and the state is a burning issue in contemporary South African society. Tutu has a clear view of his role in politics and of his relationship with both the apartheid 
and post-apartheid South African state. He was frustrated by a lack of understanding from his opposition against his role as Christian in relation to politics and the state. Tutu understands that the church is independent and autonomous from the state and partisan politics (Clarke 2008:344). Tutu (1982:32) believes that Christian faith and not politics should be the motive for our social involvement. This makes us responsible to critique every political system and test it against gospel standards.

Tutu's $(1982: 34,54)$ approach to the state is in line with critical solidarity (Kumalo 2009:247, 248). Churches must critique state laws and policies if these do not agree with the gospel, and they must peacefully protest for their repeal. Tutu mentions that, if the state does the correct things, it must be obeyed; but when it abuses its power, it is our Christian duty to condemn it. For example, Tutu (1982:48) mentions that he was not only negative and critical of the apartheid authorities, but he would also often send congratulatory messages to them. He congratulated the Minister of Police, Louis le Grange, during the apartheid era, for allowing political prisoners to do further studies after matriculation. In 1990, he congratulated President De Klerk for unbanning political parties and releasing Nelson Mandela (SAHO 2018).

Tutu also raised some concerns against his critiques' lack of understanding of his role as Christian in relation to politics and the state. For example, during the apartheid era, Tutu $(1982: 32,52,54)$ raised his concern against the criticism that he is promoting unrest and confrontation with the state in apartheid South Africa and that he is labelled a political "predikant", because he criticises a particular political status quo that does not benefit society. He viewed this as unfair, due to a lack of criticism of some ministers who support partisan politics such as the apartheid government and a particular political status quo that perpetuates injustices against society.

\section{Philosophy of life}

Tutu's Christian philosophy of life is embedded in an African context and is, to a great degree, influenced by the hermeneutics of suspicion. As part of his Christian philosophy, Tutu $(1982: 31,62)$ believes that believers in

2 "Predikant" is an Afrikaans word for a minister of Word, or a pastor. 
Christ are a reconciled community that must also practise reconciliation in society. Reconciliation is personal; it can happen between persons who acknowledge their personhood and respect each other. For reconciliation to be implemented, Tutu $(2010: 85,86)$ believes that there must at least be confession, forgiveness and reparations. Tutu acted as an agent of peace and non-violence against a violent and repressive nationalist government that detained people without trial. The Black community was oppressed, harassed and killed (Webster 1982:13, 14). According to Webster (1982:20), Tutu strived for a peaceful and non-violent social change. However, Tutu believed violent means is often an effective tool for freedom of the oppressed. Nevertheless, he encouraged negotiation instead of violence; he would urge western countries to exert pressure on South Africa to take part in a negotiated settlement, to mobilise for unbanning liberation movements, to sign peace accords, and to intervene in order to save people's lives (Pieterse 1995b:23; Tutu 2005:47; Tutu \& Tutu 2010:2). Tutu's philosophy mobilised him to encourage the sharing of resources for the betterment of the other. For example, Tutu $(1982: 44,98)$ once proclaimed that, if business people, including Whites, are to prosper, they should not be selfish, but share their prosperity with the Black community and be concerned with the betterment of our people by providing scholarships for education, and supporting other community and cultural projects.

\subsection{Ubuntu}

As an African with a passion to preserve African traditions of courtesy, Tutu is strongly influenced by the principle of ubuntu. According to Tutu (2010:12, 84, 99), ubuntu is about humanness, gentleness, hospitality, and putting ourselves on behalf of the other. It is about recognising our humanity as bound up with others so that we can all be human beings together. Tutu also believes that ubuntu is restricted not only to Africans, but also to all humanity. He believes that, during the apartheid era, when the perpetrators dehumanised the other, inflicting untold harm and suffering, they were inexorably also being dehumanised (Tutu 2010:84).

\subsection{Hermeneutics of suspicion}

Tutu's philosophy was also influenced, to a great extent, by the hermeneutics of suspicion which was birthed by African theology, Black theology, 
Black consciousness, and Liberation theology. Tutu understood African Theology as indigenous theology, whereby Africans endeavour to express Christianity in an authentic African way, liberate Africans from bondage, and come to an African understanding of God through a comparative study of God and the Old Testament. To Tutu (2010:11), Black theology endeavours to make sense of the life experience and humanisation of the Black person. Most importantly, Black theology is concerned with the human liberation of both Black and White people (Clarke 2008:341). Furthermore, Tutu understands liberation as a key concept of the bible. Liberation of humanity includes political, social, and economic liberation. Therefore; to Tutu (2010:1, 11, 78), liberation theology must help victims assert their humanity and be courageous against the injustices practised by the oppressors.

According to Tutu (1982:62, 64), Black consciousness is a movement whereby God sought to awaken, in a Black person, a sense of intrinsic value and worth as a child of God; there is no need to apologise for one's existential condition as a Black person; Black people should glorify and praise God who created them Black. Until Black people assert their humanity and personhood, there is no prospect of reconciliation in South Africa. Briefly, to Tutu (1982:61), Black consciousness is about building pride and awareness among Black people by demonstrating the worth of Black African culture, against a careful analysis of White settlers who stripped Black people of their freedom.

\section{Polarised public description of Tutu}

Every human being is either loved or despised by members of the community. Tutu has experienced both love and rejection by members of the community he served so eagerly. Tutu is one of the most well-known clerics in the world, a legend, an icon, a leading moral and reconciliatory voice across, and sometimes an "unreasonable man" as a leader (Rensburg 2002:752, 756). He is described as warm and outgoing, a loving but strict father (Gish 2004:35, 53; Allen 2006:170). Others describe him as a difficult person to ignore, because he lacks hatred, he loves justice and has an abundant sense of humour and concern for good relations between races (Webster 1982:16). Some people describe Tutu as a caring father in God, 
a spiritual counsellor, a man of prayer who exercises retreat, Eucharist, and daily prayer (Clarke 2008:416). Others describe Tutu as a theologian, a preacher, and a church leader for a peaceful change in South Africa (Pieterse 1995a:1-8).

By contrast, according to Crompton (2007:33, 47, 52, 71, 77), critics also gave Tutu derogatory names. They sometimes called him a hypocrite, and a 'job jumper'. The apartheid government described him as a gadfly at most; they viewed him as not very important as far as the government was concerned. Furthermore, during the apartheid regime, some conservative Whites swore at and insulted him. His critics also called him rabble-rousing priest because of being vocal in his standpoint against the apartheid policy. According to Tutu $(1982: 52,53)$, in political circles during the apartheid era, his critics used to call him a political hothead, because he criticised apartheid; to some Whites, he was an irresponsible radical fire-eater who should have long been locked up, banned, had something equally horrible happen to him, an ogre, and a pastor trying hard to be a politician. During the apartheid era, the young Black youths criticised his pacifist ideas as inadequate for the 1990s. As a TRC chairperson, he was criticised for his merciful and compassionate ways toward old leaders of the apartheid system and for using the TRC to prosecute former struggle activists such as Winnie Mandela. According to Tutu (1982:49) and Clarke (2008:416, 422, 432), some sectors of his church and other Christian sectors criticised him. For example; some White congregations from the CPSA threatened to leave if Tutu were to lead them (Crompton 2007:38). As Archbishop of the CPSA, he was criticised by the Gospel Defence league, which rejected his public statements. Independent Christian structures such as the Independent Reform Churches, the Dutch Reformed Church and the Christ League of South Africa criticised Tutu for his statements during his leadership ministry, especially during the apartheid era.

Tutu's critics did not simply use name-calling and derogatory descriptions; some also physically threatened him and his family to deter him in his course. Tutu received horrifying letters and telephone calls, and his family was threatened by obscene and demented calls (Crompton 2007:53; Tutu 1982:53). Tutu's house was once subjected to sounds of hooters and lights by unknown people who intend to intimidate him (Clarke 2008:423). 


\section{Tutu's contribution towards development in South African society}

Development is intrinsically related to diakonia, hence Phiri and Kaunda (2016:185) argue that the focal point of development and diakonia is upholding of the human value. To achieve that, both development and diakonia need to conscientise human beings about the potential manipulation and exploitation by the surrounding social forces and structures. Not only that, development and diakonia must also provide skills and strategies to confront the evil social forces and structures and develop an alternative solution.

According to WCC (2012, paragraph 4) diakonia involves both actions of care, relief and service, including confronting the root causes of injustices. This confrontation of the injustices must both be transforming and prophetic. It is transforming when it effects deep change in people, systems and concrete situations of life of those who are marginalised. It is prophetic when it confronts the evil structures, the powers and principalities that oppress, exploit and wound all who are created in God's image. Moreover, diakonia promotes development of human beings to be able to address the human needs in crisis situations, and for advancing the course of justice and economic development of those in need (WCC 2012, paragraph 6). Hence, one can say diakonia and development function well when they focus on human development.

Development when integrated with diakonia and driven by the motives of gospel values, it becomes part of the mission of the local church. This we realise when development enables human beings to live life in fullness and being courageous to confront injustices that hinder life in fullness. Hence, development must engage humanity and confront social injustices.

Tutu was passionate about the development of the South African society. In this article Korten's (1990:113-128) four-generation development theory will be used to analyse the contribution of Tutu's leadership ministry in the development of the South African society. This Korten's four-generation development theory has four strategies of social development related with each generation theory. Swart (2006) adapted this Korten's four-generation development theory to be used to analyse the social involvement ministry by the church. 


\subsection{The welfare strategy (Generation 1)}

Korten (1990:115) says that in this strategy, one volunteers and act to provide relief to an emergency. The kind of help offered to the beneficiaries is humanitarian aid to address the immediate need of food, health care, and shelter. To sustain this kind of help, it depends on availability of funds, staff and administrative capability. The disadvantage with this approach is that it promotes passivity on the part of the beneficiaries, and a paternalistic attitude on the part of the benefactors. This is because the relief is a temporary alleviation of the needs and do not contribute much to development assistance (Korten 1990:116).

Tutu $(1982: 16,46)$, through various structures of the SACC. He contributed to the welfare of families of banned political prisoners and of those suffering from the injustices of the apartheid government. This he did by providing them with work to earn a living, money for burial and food to sustain them through difficult times and with legal aid to assist in the proper administration of justice against the apartheid government. Furthermore, Tutu $(1982: 29,31)$ in addressing these immediate needs of the families of the political prisoners, he was inspired by the scripture and encouraged others to partake in offering this kind of help to those in need. For example, "we qualify ourselves for heaven by whether we have fed the hungry, clothed the naked, visited the sick or those imprisoned (Isa 58:1-8)"

Tutu's contribution to the development in South Africa did not end with the welfare strategy to address the immediate needs. He was willing to shift to a better development approach, hence he had courage to challenge other institutions like the WCC to shift from this welfare approach. This he did by warning the WCC that continuous humanitarian aid does not alleviate suffering (Webster 1982:16). Rather, it encourages the recipients to acquiesce in their condition and incites the almsgiver to avoid confronting and changing the basic situation that elicited the need for alms (Clarke 2008:368).

\subsection{The small-scale community development strategy (Generation 2)}

Korten (1990:118) states that this strategy focuses on community selfhelp actions in various sectors of the economy, culture, and politics. The purpose is to help people with skills that they can use to address their 
own human needs and become self-reliant. Factors like tradition, lack of education and others may be hindrance towards becoming self-reliant (Korten 1990:119). To overcome that, external intervention towards self-reliance and self-advancement should be through empowerment, partnership and offer opportunity for the beneficiaries to partake in decision making and implementation so that the community members may realise their potential. In this strategy the agent of intervention plays a role of a facilitator, or mobiliser. The problem with this approach is that the external intervention needs to ensure that the skill addressed is relevant and appropriate for self-reliance. This is because often the interventions done are given as sophisticated guise of handout, which give a lip service to self-reliance and make beneficiaries dependent on the donor. Another challenge in this strategy is that the scope of impact of development is limited to the local area and does not influence the national or international policy makers and institutional designers.

Using the SACC's theological funds for study, Tutu helped many South Africans by providing, in SACC, menial jobs to students and funds for those who want to study Theology. Through the SACC, Tutu (1982:51) also used self-help projects for sustaining the lives of the victims of the apartheid regime. Tutu used SACC as a vehicle to contribute to alleviation of unemployment rate through helping people to produce income through self-help projects. Again, Tutu was willing to partake in community projects that would make available community services such as tarred roads, proper sewerage, and paved sidewalks.

\subsection{The sustainable development strategy (Generation 3)}

According to Korten (1990:120) this strategy focuses on matters beyond the local community because of the challenge that self-reliance of community members is possible only if it is linked to supportive national development policies and institutions. He argues that to achieve this link with supportive national policies and institution, the external intervention has to facilitate change in the systems, policies and institutions that hinder development so that there would be justice, sustainable and inclusive development. To bring this desired change, there is a need for collaboration and confrontation of the hindering systems, policies and institutions. This should happen whilst at the same time building capacity on the people to enable them make 
demands on the system to reap the required benefits (Korten 1990:121). Again, in achieving this desired change, the external intervention should facilitate the relationship between the community and potential key players in the system, develop in-depth knowledge of the system and build awareness of the need to transform the critical institution or system. In summary, the main goal of sustainable development strategy is to challenge dysfunctional policies, systems and institutions on all levels for the benefit of those affected on a wider scale. The disadvantage of this strategy is that it is not always easy to change policies, systems and institutions that have existed for a long time.

In relation to this strategy, Tutu (1982:54) viewed apartheid as unjust, immoral and unchristian system. As a result, he challenged the nationalist government thinking, repressive policies that destabilised South Africa and hinders the practice of justice, peace and equality between both black and white (Webster 1982: 16). Some of the actions he did to challenge the Apartheid regime was writing letters to Apartheid government officials, marching in the street, and calling for economic sanctions against South Africa (Tutu 1982:32). In his confrontation and condemning of the Apartheid system he was inspired by his Christian values, hence he says "As Christian we need to evaluate policies of the nationalist government, critique every political system and test it against gospel standards. If certain laws do not agree with the gospel we must agitate for their repeal in all peaceful means." (Tutu 1982: 33, 34).

\subsection{The people-centred development strategy (Generation 4)}

This strategy focuses on human growth in the context of values such as peace, justice and inclusiveness. It engages critical theories to challenge social injustices and links local development efforts with larger structures that directly influence the efforts. It is about empowering people to drive social change through shaping of their thoughts, spirituality, actions on the matters like environment, human rights, peace and justice (Korten 1990:124). It strives for decentralisation of structures of power to allow decision-making and control to be on the local level so that the benefits are used for enabling the beneficiaries to control their own sources. This strategy has a vision towards common good and mobilising people towards independent action by individual and organisation (Korten 1990:124). 
This independent action is the result of awakened conscience and public consciousness raised through common vision. The role of the external intervention could be to empower, motivate, share ideas and necessary resources to people movement (Korten 1990: 127). Again, the other role could be to influence members of the community towards alternative vision through ideas, vision and communication.

Tutu believed that alone he cannot win the struggle for justice. Hence, he focused on empowering and motivating other people to partake in the struggle against the Apartheid regime in their own context. Tutu's human empowerment was usually done from interpersonal relationship and public platform. For example, while at SACC he delegated some of his responsibilities to his senior staff members and often used spiritual practices like prayer and Eucharist and the scripture to direct people towards renewing their relationship with God and the other. Even though he acknowledged the iniquity of humanity, he had relatively a positive view about human beings. Hence, he says, each of us has potential to do good, and God relies and depends on us to become agents of transformation that God uses to transform the world. To help empower humanity to become partners of God and agents of transformation Tutu conducted numerous public teachings and wrote a lot about forgiveness, reconciliation, transformation of humanity and society. These teachings of Tutu were driven by his philosophy of change, which he believed should be through peace, the pursuance of justice, and non-violence. But what kind of change in humanity did Tutu desired to achieve? Tutu did want to see deep spiritual change in humanity. A change that would enable South Africans to share, and value human dignity, spirituality, justice, and reconciliation (Clarke 2008:344).

In summary, Tutu's leadership ministry touched on Korten's (1990) four strategies of social development but not all to the same degree. His participation in development of the members of the South African community was motivated by the scriptures, not necessarily political motive. The militant and the violent nature of the Apartheid regime and the tension it caused between itself and members of the black community, forced Tutu leadership to function more often on a welfare level to address the immediate humanitarian needs. However, it did not end there, as he always strived towards better approach to develop the members of the 
community of South Africa. When opportunity arises he, used a faithbased organisation like SACC to facilitate community self-help projects. Even these self-help projects were not enough for Tutu to bring sustainable human development. Hence, one can say Tutu's leadership engagement also functioned more at the systemic and structural level whereby he confronted Apartheid political power on-behalf-of the South African people. Tutu's leadership ministry did not only strive towards confronting the unjust rules and policies of apartheid, but also went deeper to challenge the thinking and the vision of separate development on a racial basis. He mobilised the local and international communities to condemn and call for transformation of the unjust Apartheid policies, structures and officials. While confronting the unjust Apartheid system Tutu also facilitated empowerment of the members of the South African society through his interpersonal interaction and public lectures. For example, he introduced his spiritual practices to his staff member at the SACC, and by delegating some of his leadership responsibilities to them (SAHO 2018; Clarke 2008:416). As Archbishop in Cape Town, he most of the time use a consensus leadership approach in order to avoid conflicts (Allen 2006:279). As Bishop of Lesotho, he also groomed a Lesotho national, Philip Mokuku, to succeed him (SAHO 2018) hence one can say Tutu's social involvement did not end with the development of the South African society but went even beyond the border of South Africa.

\section{From development to transformation in society}

According to Bragg (1987:46), development is distinct from transformation. Bowers-Du Toit (2010:268) argues that hope and spiritual transformation distinguish forms of development from ministry of transformation. According to Bragg, in order to shift towards a transformation of society, the following aspects need to be considered: life sustenance, equity, justice, dignity and self-worth, freedom, participation, reciprocity, cultural fit, ecological soundness, hope, and spiritual transformation. Intense study of the life narrative of Tutu proves that, Tutu's leadership in social development did endeavour to engage majority of the aspects mentioned above by Bragg. Some of the above-mentioned aspects by Bragg are discussed elsewhere in the article, due to lack of space only hope and spiritual transformation will be discussed as essential elements of social transformation. 
- Hope implies that transformation is hope, for without hope, change rarely happens. To Tutu, religion and church must give hope to those who are hopeless (Tutu 1982:36).

- Concerning spiritual transformation, the core of human and social transformation is spiritual. Without a deep change of inner being, humanity remains self-centred. Bowers-Du Toit $(2010: 268,269)$ argues that, in order to contribute towards social transformation, the agent, be it a church or an individual, must first be transformed in order to become a transformative agent in society. For authentic transformation to happen, the church or the individual must engage the structure and spirituality of the system in order to transform relationships. Personal transformation must be prioritised before social transformation (Du Toit 2009:21, 22).

Tutu's spirituality empowered him to act as a transforming agent for the church, the organisations and the society he served. He wanted to see the change brought by his leadership ministry in the South African society. This change was not simply a cosmetic change or a re-arrangement of things, but a fundamental change of humanity (Tutu 1982:88; Clarke 2008:344). For example, Tutu criticised reckless Black taxi-drivers who despise themselves and other Black people but fear White people and the police in town. He says those maverick and reckless taxi-drivers need to be spiritually liberated not to despise themselves and other Black people, because the latter must have pride and self-respect (Tutu 1982:78). During the apartheid era, Tutu implored the White people to change. For example, he urged them to voluntarily change their high standard of living and their attitude, as Black people are also human (Tutu 1982:44, 45). Briefly, Tutu did insist on pursuing spiritual transformation in order to transform some of the human actions in society. In his sermons, social actions and personal devotion, Tutu often mentioned hope as part of the religious or church activities in society.

\subsection{Towards transformation in society}

Based on his leadership ministry through sermons, social action and personal devotion, Tutu always insisted on having hope for the future and striving for transformation of relationship with each other, God and the 
environment and of the unjust social system and policies of the nationalist government.

How did Tutu understand transformation? Tutu preferred to use transfiguration to delineate transformation. Tutu (2005:3) argues that transfiguration is divine transformation. It is a process of releasing one from bondage and opens us to glorify God. To Tutu (2005:53) transfiguration is radical transformation, not just cosmetic change or rearrangement of structure. Transfiguration it goes deeper to remove that which is festering, it cleanses, cauterises so that new beginning becomes possible. For his explanation of transfiguration, Tutu (1994:118) favoured metaphors such as when winter gives way to spring; wine and bread lifted to a higher order of being, and channel for divine life. According to Tutu, the principle of transfiguration says nothing; no one, no situation cannot be transfigured. Transfiguration avers that an erstwhile persecutor can become the greatest missionary (Paul), one who denies that his master can become the prince of apostles (Peter). After the demise of Apartheid regime in 1994 and the potential challenges of AIDS, poverty and unemployment in South Africa, Tutu (2005:7) argued that transfiguration does not end with Apartheid regime, but it is an ongoing event to engage new problems of individuals and situation.

Furthermore, Tutu (2005:vii,viii,15,16) believes that God is the author of transformation in us and the world. To transform the world God uses us as partners and agents of transformation. This is despite our flaws because God knows our capacity and potential we must achieve and perform His will in the world.

\section{Lessons derived from Tutu's leadership ministry}

Considering the above discussions, we realise that Tutu was one of the vessels that God used to serve the world, be the advocate of the oppressed, and confront the perpetrators during the apartheid regime in South Africa, in order to transform the situation towards what God intends it to be. Tutu is an astute theologian, unflagging servant of the Lord, caring father, and a compassionate and transforming leader with a humorous and courageous personality and spirituality. He adores not only personal devotion to God, but also concrete social involvement. 


\subsection{The following lessons can be derived from Tutu:}

First, Tutu's theology was influenced by African, liberation and Black theologies, resulting in his leadership ministry being radical, contextual, critical and relevant to the situation of South Africa. These theologies helped Tutu to challenge the hidden or visible powers within the public systems, structures and policies. These theologies influenced Tutu to take a stand of understanding religion and God as not neutral but taking side especially of the weak and marginalised.

Second, effective Christian leadership is characterised by clear theology of social action and mobilising humanity towards a transforming relationship with God. Tutu's leadership engaged in social action on congregational, social and even global levels. The activities for his social ministry contributed to the social, economic, political and environmental development of the South African society. Furthermore, through his integrity, prayer, Bible study and sermons, he continuously endeavoured to mobilise the South African society to develop hope and trust in God for freedom and a peaceful, non-violent transition to a new South Africa.

Third, Tutu's leadership functioned within and beyond the church boundaries. Tutu refused to yield to the critiques that Christians, Christian religion or a church should focus on personal devotion at the expense of concrete action against social injustices. He believed that Christians, Christian religion or a church must be involved in transforming unjust situations and give hope to the poor and the marginalised. Hence his leadership ministry challenged the stereotyped ministry of his church when he practised ministry that is non-racial and concerned with context beyond the church borders. He sternly criticised the apartheid government and its policies. Internationally, Tutu was a member of various organisations, enabling him to visit various countries to promote peace, reconciliation and justice and mobilise against the Apartheid regime of South Africa.

Fourth, to Tutu, the motive for our social involvement was to be driven by the imperatives of the gospel, not the human selfish agenda. Tutu had a good knowledge of scripture (Romans 12:1-2; Ephesians 5:8-12; Genesis 1,2 ; Isaiah 58:1-8) that justified his actions towards the social development and transformation of the South African society. 
Fifth, Tutu's leadership engaged all the strategies of Korten's four-generation development theory though one cannot say he used all theories to the same degree. He gave food, money, and employment, and even challenged the policies and laws that contribute to the unjust situation of the poor and the oppressed on both national and international level. Tutu's development of the South African society engaged human empowerment and growth; this was a people-centred African development. For this reason, it can be said that Tutu's social development was localised and invested not necessarily in structures, but also in the ability of the South African community to bring out its members' potential, so that they can mobilise towards their own direction (Speckman 2007:44). To Tutu, structures such as a church and the SACC were simply temporal vehicles to achieve the will of God. To Tutu it is important to empower people to develop their own future. Tutu rejected or challenged whatever impeded this goal. For example, he knew the negative impact of continuous aid, as it promotes dependency of the recipients. Tutu may have been aware of the other negative consequences of continuous aid: delayed institutional maturation, retarded growth, it kills initiative, and encourages one to be a beggar (Speckman 2007:13, 15).

Sixth and lastly, Tutu's leadership never ended with human development, but he also strived towards both external and internal transformation. Tutu's leadership strived for a fundamental change of the laws, rules, and policies of apartheid, human need for aid to self-empowerment and freedom, and thinking and vision. Furthermore, he strived to change the relationship of humanity with God, the environment and other human beings. He challenged the thinking, vision, values and practices of the apartheid government, as well as both Black and White races by encouraging different races to reconcile and live in peace and by using radical theology and key biblical concepts of reconciliation, justice and peace to mobilise humanity towards having a transforming relationship with God. He condemned the discriminatory practices of apartheid government officials, the vision of apartheid as separate development of different races, the police, and the evil structures of apartheid such as the homelands and the Bantu education system. In conclusion, Tutu's leadership went beyond the development of the South African society towards giving hope to the poor, and promoting spiritual empowerment that strives for social transformation, and challenges social injustices. 


\section{Conclusion}

Christian leadership and churches are faced with complex, rapid and discontinuous change from both their immediate context and internal ministry. This has caused conflict and tension in the role of the church and Christian leadership in the development of society. Some vow for religious piety with less concrete action, while others support social activism often without spiritual discernment. During this uncertainty and tension, Tutu's leadership provided some guidance and an example of how Christian leadership can practise effective ministry in the development and transformation of a society through churches or parachurches. Tutu's leadership contributed to the development of the South African society during and after the apartheid era. For the effective development of South African society, Tutu's leadership invested considerably in an understanding how Christian leadership could use Christian religion to contribute towards development and transformation of a South African society. Hence, Tutu's leadership emphasised the practice of personal devotion that influences our public life and mobilises towards social action.

Tutu's leadership made a formidable impact on the social, political, economic and environmental development of the South African society and the world. Tutu's development of the South African society impacted on various levels, namely the congregation, society, and the global society. In his congregations, he modernised liturgy, and challenged the stereotype thinking when he advocated for women ordination and the rights of gays and lesbians. In society, he challenged the unjust practices of the nationalist government, in both Black and White communities. Globally, he was outspoken against Apartheid regime, and against countries and organisations that perpetuate global injustices. Tutu's leadership impact did not end with the development of the South African society. He strived for transformation of society. This involved deep change from a spirituality that favours personal piety towards the one that extends personal piety to social action, hope, and a deep change from apartheid's vision of separate development of races to a vision that strives for justice, unity and reconciliation of races, and the change of rules, policies and laws that perpetuate injustices to those that promote justice and peace. 
In summary, Tutu's leadership contributed to the social, political, economic and environmental development and transformation of the South African society. The impact of Tutu's leadership was lis considerable, as it contributed towards the demise of apartheid, a relatively peaceful and non-violent transition to democratic South Africa, and a rainbow nation that embraces diversity and strives towards working together for justice and peace. Tutu's leadership is a model of Christian leadership from which we could learn about how Christian religion, and churches should influence our practising of Christian leadership, especially in this society. Tutu's leadership was and is effective in many aspects, namely in human empowerment, in confronting unjust social structures, facilitating humanitarian aid and in transforming a violent and tense context into a peaceful one. In response to the research question of this article, "To what extent was is the leadership of Tutu involved in the social development of the South African society", it can be stated that Tutu's leadership was very involved in the development of the South African society and its transformation. The South African churches, society, and social policies benefited from Tutu's leadership ministry. The social, political, and economic development of the South African society were engaged by Tutu's leadership for the purpose of transformation. Lastly, the development and transformation practices of his leadership targeted local structures such as the church and society on both national and international levels. In conclusion, Tutu's leadership did contribute towards the social development and transformation of the South African society.

\section{Bibliography}

Allen, J. 2006. Rabble-rouser for peace: The authorised biography of Desmond Tutu. London: Rider.

Bowers-Du Toit, N. 2010. Moving from development to social transformation: Development in the context of mission. In: I. Swart, H. Rocher, S. Green \& J. Erasmus (eds.). Religion and social development in post-apartheid South Africa: Perspectives for critical engagement. Stellenbosch: Sun Press. 261-274. 
Bragg, W.G. 1987. From development to transformation. In: V. Samuel \& C. Sugden (eds.). The church in response to human need. Oxford: W.B. Eerdmans. 20-51.

Browning, D. 1991. A fundamental practical theology. Minneapolis: Fortress Press.

Burns, M. 1979. Leadership. Perennial: First Harper paperback.

Chakraborty, S.K. \& Chakraborty, D. 2004. The transformed leader and spiritual psychology: A few insights. Journal of Organisational Change Management, 17(2):194-210.

Clarke, B. 2008. Anglicans against apartheid 1936-1996. Pietermaritzburg: Cluster Publications.

Clark, S.C. 1961. Unity, uniformity and the English church. London: Morbray, A.R. and Co limited.

Cochrane, J., De Gruchy, J. \& Peterson, R. 1991. In word and deed. Towards a practical theology of social transformation. Pietermaritzburg: Cluster Publications.

Crompton, S.M. 2007. Modern peacemakers. Desmond Tutu. Fighting apartheid. New York: Chelsea House Publishers Infobase Publishing.

Dayton, E.R. 1987. Social transformation. The mission of God, in V. Samuel \& C. Sugden (eds.). The church in response to human need. Oxford: W.B. Eerdmans. 52-61.

Du Toit, C. 2009. African challenges: Unfolding identities. Pretoria: Unisa Press.

Ford, L. 1991. Transforming leadership. Downers Grove: Intervarsity Press.

Gish, S. D. 2004. Desmond Tutu: A biography. London: Greenwood Press. Heitink, G. 1999. Practical Theology Manual: History, theory and action domain. Grand Rapids: W.B. Eerdmans.

Jinkins, M. 2000 Religious leadership, in B.J. Miller-Mclemore. The Wiley-Blackwell companion to Practical Theology. Oxford: Blackwell. 308-314. 
Kumalo, S.R. 2009. The people shall govern. The role of the church in the development of participatory democracy in South Africa. Scriptura, 101:246-258.

Pieterse, H.J.C. 1995a. Preface. In: H.J.C. Pieterse (ed.). Desmond Tutu's message: A qualitative analysis. Theologie and Empirie. Kampen: Kok Pharos Publishing House. 1-8.

Pieterse, H.J.C. 1995b. The context of apartheid. In: H.J.C. Pieterse (ed.). Desmond Tutu's message: A qualitative analysis. Theologie and Empirie. Kampen: Kok Pharos Publishing House. 15-25.

Pieterse, H.J.C. \& Scheepers, P. 1995. Introduction: Tutu's message in perspective. In: H.J.C. Pieterse (ed.). Desmond Tutu's message: A qualitative analysis. Theologie and Empirie. Kampen: Kok Pharos Publishing House, 9-14.

Plueddemann, J.E. 2009. Leadership across cultures. Grand Rapids: W. B. Eerdmans.

Rensburg, R. 2002. Archbishop Desmond Tutu as moral sage and servant leader:A compassionate zealot. Verbum et Ecclesia, JRG 23 (3): 746-761.

Roxburgh, A.J. \& Romanuk, F. 2006. The missional leader. San Franscisco: Jossey-Bass.

Saines, D. 2010. Wider, broader, richer: Trinitarian theology and ministerial order. Anglican Theological Review, 92(3):511-535.

Schoeman, K., Laubscher, M., Pali, J. \& Van Den Berg, J.A. 2012. Practical theology at a public university: The road travelled and the road ahead at the University of the Free State, in R. Venter \& F. Tolmie (eds.). Transforming theological knowledge: Essays on theology and the University after apartheid. Bloemfontein: Sun Press. 127-143.

Smit, A. 2001. Meetings that matter: Leadership, spirituality and discernment in congregations. Wellington: Lux Verbi.

Speckman, M.T. 2007. A Biblical vision: For Africa's development. Pietermaritzburg: Cluster Publications. 
Swart, I. 2006. The churches and the development debate: Perspectives on a fourth-generation approach. Stellenbosch: Sun Press.

Tannenbaum, R., Weschler, I.R. \& Massarik, F. 2013. Leadership and organisation: A behavioural science approach. New York: Routledge.

The Wheaton '83 statement. 1987. Transformation: The church in response to human need, in V. Samuel \& C. Sugden (eds.). The church in response to human need. Oxford: W. B. Eerdmans. 254-265.

Tutu, D. 1982. Jesus Christ-The man for Others. In: Webster, J., (ed.). Bishop Tutu - the voice of the one crying in the wilderness: A collection of his recent statements in the struggle for justice in South Africa. Mowbray: Oxford, pp 27-30.

Tutu, D. 1982. The church in the world. In: Webster, J., (ed.). Bishop Tutu - the voice of the one crying in the wilderness: A collection of his recent statements in the struggle for justice in South Africa. Mowbray: Oxford, pp 30-33.

Tutu, D. 1982. Politics and religion. In: Webster, J., (ed.). Bishop Tutu the voice of the one crying in the wilderness: A collection of his recent statements in the struggle for justice in South Africa. Mowbray: Oxford, pp 33, 34.

Tutu, D. 1982. The theology of Liberation. In: Webster, J., (ed.). Bishop Tutu - the voice of the one crying in the wilderness: A collection of his recent statements in the struggle for justice in South Africa. Mowbray: Oxford, pp 34-36.

Tutu, D. 1982. Crisis and response. In: Webster, J., (ed.). Bishop Tutu the voice of the one crying in the wilderness: A collection of his recent statements in the struggle for justice in South Africa. Mowbray: Oxford, pp 39.

Tutu, D. 1982. To the White South African community. In: Webster, J., (ed.). Bishop Tutu - the voice of the one crying in the wilderness: A collection of his recent statements in the struggle for justice in South Africa. Mowbray: Oxford, pp 44-45. 
Tutu, D. 1982. The South African Council of Churches-Our work at the grassroots. In: Webster, J., (ed.). Bishop Tutu - the voice of the one crying in the wilderness: A collection of his recent statements in the struggle for justice in South Africa. Mowbray: Oxford, pp 46-49.

Tutu, D. 1982. In Defence of the SACC. In: Webster, J., (ed.). Bishop Tutu - the voice of the one crying in the wilderness: A collection of his recent statements in the struggle for justice in South Africa. Mowbray: Oxford, pp 49-52.

Tutu, D. 1982. Where I stand. In: Webster, J., (ed.). Bishop Tutu - the voice of the one crying in the wilderness: A collection of his recent statements in the struggle for justice in South Africa. Mowbray: Oxford, pp 52-55.

Tutu, D. 1982. Steve Biko-A Tribute. In: Webster, J., (ed.). Bishop Tutu the voice of the one crying in the wilderness: A collection of his recent statements in the struggle for justice in South Africa. Mowbray: Oxford, pp 61-64.

Tutu, D. 1982. Black consciousness and Car Driving. In: Webster, J., (ed.). Bishop Tutu - the voice of the one crying in the wilderness: A collection of his recent statements in the struggle for justice in South Africa. Mowbray: Oxford, pp 78-79.

Tutu, D. 1982. Where I stand. In: Webster, J., (ed.). Bishop Tutu - the voice of the one crying in the wilderness: A collection of his recent statements in the struggle for justice in South Africa. Mowbray: Oxford, pp 52-55.

Tutu, D. 1982. Black Consumer Power-One lever for change. In: Webster, J., (ed.). Bishop Tutu - the voice of the one crying in the wilderness: A collection of his recent statements in the struggle for justice in South Africa. Mowbray: Oxford, pp 97-98.

Tutu, D. 1982. My vision for South Africa. In: Webster, J., (ed.). Bishop Tutu - the voice of the one crying in the wilderness: A collection of his recent statements in the struggle for justice in South Africa. Mowbray: Oxford, pp 99-101.

Tutu, D. 1982. A prophetic Church and Human rights in the Third World. In: Webster, J., (ed.). Bishop Tutu - the voice of the one crying in the wilderness: A collection of his recent statements in the struggle for justice in South Africa. Mowbray: Oxford, pp 113-115. 
Tutu, D. 1982. Divided Churches. In: Webster, J., (ed.). Bishop Tutu - the voice of the one crying in the wilderness: A collection of his recent statements in the struggle for justice in South Africa. Mowbray: Oxford, pp 115-119.

Tutu, D. 1994. We drink water to fill our stomachs (1979). In: Allen, J., (ed.). Desmond Tutu: The rainbow people of God. South Africa's history over apartheid. New York: Doubleday, pp 25-41.

Tutu, D. 1994. The Divine imperative (1982). In: Allen, J., (ed.). Desmond Tutu: The rainbow people of God. South Africa's history over apartheid. New York: Doubleday, pp 53-78

Tutu, D. 1994.Agents of transfiguration (1986). In: Allen, J., (ed.). Desmond Tutu: The rainbow people of God. South Africa's history over apartheid. New York: Doubleday, p 109-124.

Tutu, D. 1994. Nurturing our people (1992). In: Allen, J., (ed.). Desmond Tutu: The rainbow people of God. South Africa's history over apartheid. New York: Doubleday, pp 227-232.

Tutu, D. 2007. Foreword. In: Van Rensburg, G., (ed.). The leadership challenge in Africa. Pretoria: Van Schaik Publishers. v-vi.

Tutu, D. 2005. God has a dream: A vision of hope for our time. London: Rider.

Tutu, D. 2010. On African churches. In: Shepherd, D., (ed.). In the words of Desmond Tutu. Rosebank: Penguin, pp 1, 2.

Tutu, D. 2010. On Black Theology. In: Shepherd, D., (ed.). In the words of Desmond Tutu. Rosebank: Penguin, pp 10-11.

Tutu, D 2010. On BotholUbuntu. In: Shepherd, D., (ed.). In the words of Desmond Tutu. Rosebank: Penguin, pp 12-13.

Tutu, D 2010. On the church. In: Shepherd, D., (ed.). In the words of Desmond Tutu. Rosebank: Penguin, 16-17.

Tutu, D 2010. On leadership. In: Shepherd, D., (ed.). In the words of Desmond Tutu. Rosebank: Penguin, p 29.

Tutu, D 2010. On People. In: Shepherd, D., (ed.). In the words of Desmond Tutu. Rosebank: Penguin, p 44. 
Tutu, D 2010. PW Botha, Former State President. In: Shepherd, D., (ed.). In the words of Desmond Tutu. Rosebank: Penguin, p 45-46.

Tutu, D 2010. On the Priesthood. Shepherd, D., (ed.). In the words of Desmond Tutu. Rosebank: Penguin, p 60.

Tutu, D 2010. On religion. Shepherd, D., (ed.). In the words of Desmond Tutu. Rosebank: Penguin, p 64.

Tutu, D 2010. On the Anti-apartheid struggle. In: Shepherd, D., (ed.). In the words of Desmond Tutu. Rosebank: Penguin, p 77-82.

Tutu, D 2010. On the truth and reconciliation concept. In: Shepherd, D., (ed.). In the words of Desmond Tutu. Rosebank: Penguin, pp 84-87.

Tutu, D. \& Tutu, M. 2010. Made for goodness and why this makes all the difference. London: Rider.

Van der Borght, E.A.J.G. 2005. To be or not to be - the identity of the minister in terms of his office within reformed tradition. Nederduitse Gereformeerde Teologiese Tydskrif, 46(1 \& 2):234-246.

Webster, J. 1982. Introduction. In: Webster, J., (ed.). Bishop Tutu - the voice of the one crying in the wilderness: A collection of his recent statements in the struggle for justice in South Africa. Mowbray: Oxford, pp 13-23.

\section{Online sources}

Barnett, J. 2016. Advent 1: Isaiah 2:5. In: We call ourselves liberal AngloCatholics. What do we mean? Series of homilies for Advent 2016, pp 1-3. [Online] http://www3.sympatico.ca/saint.matthias/Advent $\% 202016 \% 20$ Complete\%201-4.pdf [Accessed: 21 February 2019].

Dietrich, S. 2016. "For Thus Says the Lord": Prophetic Diakonia as Advocacy and Fight for Justice. In: Dowsett, R. Phiri, I. Birdsall, D. Terfassa, D.O. Yung, H \& Jørgensen, K., (eds). Evangelism \& Diakonia in Context, Edinburgh Centenary, Vol 32 of Regnum Edinburgh centenary series. Oxford: Regnum Books International, pp 153-165. [Online] http://www.ocms.ac.uk/regnum/downloads/Evangelism_and_Diakonia_in_ Context-wm.pdf [Accessed: 21 February 2019]. 
Korten, D.C. 1990. Getting to the $21^{\text {st }}$ century: voluntary action and the global agenda. West Hartford, Conn: Kumarian Press.

Kemper, A. 2016. Advent 2: Romans 15:4. In: We call ourselves liberal Anglo-Catholics. What do we mean? Series of homilies for Advent 2016, pp 4-7. [Online] http://www3.sympatico.ca/saint.matthias/Advent $\% 202016 \% 20$ Complete\%201-4.pdf [Accessed: 21 February 2019].

Lynch, G. 2017. On Anglo-Catholicism. [Online]. http://www.sarum.ac.uk/onanglo-catholicism-by-gerry-lynch [Accessed: 15 Feb 2019].

Phiri, I. A. \& Kaunda, C.J. 2016. Diakonia and Development in a Rapidly Changing World. In: Dowsett, R. Phiri, I. Birdsall, D. Terfassa, D.O. Yung, H \& Jørgensen, K., (eds). Evangelism \& Diakonia in Context Edinburgh Centenary, Vol 32 of Regnum Edinburgh centenary series. Oxford: Regnum Books International, pp 180-192. [Online] http:// www.ocms.ac.uk/regnum/downloads/Evangelism_and_Diakonia_in_Context-wm.pdf [Accessed: 21 February 2019].

SAHO. 2018. Archbishop Emeritus Desmond Mpilo Tutu. [Online] http:// www.sahistory.org.za/people/archbishop-emeritus-desmond-mpilo-tutu [Accessed: 23 April 2018].

The Cape Times. 2013. The man who changed my life. [Online] https:// www.iol.co.za/capetimes/the-man-who-changed-my-life-1533199 [Accessed: 21 February 2019].

World Council of Churches (WCC). 2012. Theological Perspectives on Diakonia in $21^{\text {st }}$ Century. From the conference jointly organized by the Justice and Diakonia, Just and Inclusive Communities, and Mission and Evangelism programmes of the World Council of Churches in Colombo, Sri Lanka, 2-6 June 2012. [Online] https://www.oikoumene. org/.../theological-perspectives-on-diakonia-in-21st-century [Accessed: 21 February 2019]. 